\title{
RATIO ANALYSIS SPECIFICS OF THE FAMILY DAIRIES' FINANCIAL STATEMENTS
}

\author{
Aleksandra Mitrović1, Snežana Kneževič ${ }^{2}$, Milica Veličkovićc ${ }^{3}$
}

\begin{abstract}
Summary
The subject of this paper is the evaluation of the financial analysis specifics of the dairy enterprises with a focus on the implementation of the ratio analysis of financial statements. The ratio analysis is a central part of financial analysis, since it is based on investigating the relationship between logically related items in the financial statements to assess the financial position of the observed enterprise and its earning capacity. Speaking about the reporting of financial performance in family dairies, the basis is created for displaying techniques of financial analysis, with a special indication on the specifics of their application in agricultural enterprises focusing on companies engaged in dairying. Applied in the paper is ratio analysis on the example of a dairy enterprise, i.e. a family dairy operating in Serbia. The ratio indicators are the basis for identifying relationships based on which by comparing the actual performance and certain business standards differences or variations are identified.
\end{abstract}

Key words: financial analysis, financial ratio, family dairy, management, financial performance.

JEL: $M 41, Q 12$

\section{Introduction}

The challenges faced by agriculture - low selling price, rising production costs and other factors significantly affect revenues worldwide. The decline of traditional rural industrial branches, such as agriculture, mining and forestry in the past three decades have led the rural communities to explore and implement alternative ways of

1 Aleksandra Mitrović, M.Sc., Teaching Assistant, University of Kragujevac, Faculty of Hotel Management and Tourism, Vojvođanska street no. 5a, Vrnjačka Banja, Republic of Serbia, Phone: +381 36515 0024, E-mail: aleksandra.stankovic@kg.ac.rs

2 Snežana Knežević, Ph.D., Associate Professor, University of Belgrade, Faculty of Organizational Sciences, Jove Ilića street no. 154, 11000 Belgrade, Republic of Serbia, Phone: +381 11395 0875; E-mail: snezana.knezevic@,fon.bg.ac.rs

3 Milica Veličković, Export Manager, Family dairy Veličković, Alakince nn, 17530 Surdulica, Serbia, Phone: +381 178120 99; E-mail: velimilk@hotmail.com

EP 2015 (62) 4 (1061-1078) 
strengthening their economic base. The decrease in the capabilities of agriculture to generate sufficient income caused many farmers to seek new sources of income and to make the diversification of products.

If we specifically observe milk production, we will see the following: The world demand for milk and dairy products in recent years has increased from 2 to $2.5 \%$ per year, while demand for milk powder and whey powder increased by $30 \%$ over the period from 2010 to 2013. Stated as the key of the increase are the needs of developing countries and China. Dairy giants such as Tetra Pak in Sweden or GEA in Germany noted as well that the activity of their enterprises increased by 10\% in 2012 (Geman, 2015).

Danish-Swedish company Arla Foods in 2012 achieved a production of 13.5 billion liters of milk and income of 9 billion euros, becoming the first company in the milk production in Europe, ahead of Friesland Campina in the Netherlands and Sodiaal from France. In 2012, Arla Foods has made a merger with Milch-Union, German leader in the production of milk, processing 1.3 billion liters of milk per year; also with a British company specialized in the production of cheese Milk Link; and more recently with the German dairy MUH. Arla Foods is building a huge factory for milk processing near London, which should produce more than 1 billion liters of pasteurized milk per year. However, as a lack of these mergers it has been observed that Arla Foods has to have a uniform price of milk i.e. the highest price among all the producers owned, so that, for example: the merger with the company MUH led to an increase in milk prices by 4 cents per liter in Germany. The projected growth in sales of dairy products in China for the period 2013-2018 was $8.5 \%$ for milk, although milk and dairy products are not part of the traditional Chinese diet. New Zealand has become a major player in the market of the so-called "white gold". France is the second largest milk producer in Europe after Germany and has already started to export to China. Chinese companies also invest in other European countries such as Germany, Ireland, Denmark, to ensure that their milk delivery and benefit from the international knowledge in the dairy industry that does not yet exist in China (Geman, 2015).

Alsos, Ljunggren, Pettersen (2003) point out that human capital as an important resource based on education or work experience is an important factor for starting new business activities. Pyysiäinen, Anderson, McElwee, Vesala (2006) are engaged in the research of developing the entrepreneurial skills of farmers and emphasize that developing the entrepreneurial skills of farmers was one of the Third Call tasks in the $6^{\text {th }}$ Research Framework Programme of the European Union (McElwee, 2005).

Accounting performance measurement is essential for financial planning and control, which are the key activities of the management process in family dairies, for the realization of financial goals of the operation, as well as for motivating and controlling the activities of managers. 


\section{Methodology and Data Sources}

The paper's aim is the consideration of the specifics of the financial analysis of the dairy enterprises and the importance of the obtained financial indicators for managerial decision-making, but also for assessing the realization by various stakeholders. The consideration of existing knowledge about the researched topic was carried out through a theoretical analysis, supported by data from domestic and foreign scientific and professional literature. The research was approached through the use of case study. Desk research method was used through the study of relevant literature in the part relating to the specificity of agricultural activities and application of basic technique of financial analysis (ratio analysis) in the case of enterprise operating in Serbia.

This research created the basis of pragmatic contribution of the paper in the field of application of financial indicators in the case of the specific enterprise. Pointed out is the importance of ratio analysis as one of the key techniques in financial analysis for monitoring the performance of dairy enterprises and thus indicated to management that they should particularly be focused on this field.

The first part of the paper is dedicated to reporting on financial performance in the family dairies. Presented after that are the techniques of financial analysis pointing out the specifics of their application in agricultural enterprises with a focus on companies engaged in dairying. This is followed by a practical example, the financial analysis of a local company which specializes in dairy production.

\section{Reporting on financial performance in family dairies}

Specifics of agricultural enterprises, which greatly affect both the financial statements of these companies and the analysis itself of the financial statements of these companies, are the following (Milošević, 1997):

- biological characteristics of the subject of work;

- climatic conditions;

- the structure and soundness of soil;

- incompatibility of the work process and production period;

- inseparability of production of certain products;

- production for their own needs, etc.

The specificity of agricultural activities is determined by a number of special features of financial accounting, on one hand, through the assets and results, and on the other hand, from the standpoint of specific documents that appear. Most of the business organizations involved in agricultural activities are relatively small, independent, usually family associations or family companies, oriented towards the cash basis of accounting, which often do not have the obligation to prepare financial statements. Moreover, the international tendency towards liberalization, a larger number of companies of international trade, as well as higher volume of investments, have an impact on the increase in enterprises in the field of agriculture, the area of change and 
the commercial character of agricultural activity. The previously mentioned determines even greater need for the financial statements prepared respecting IFRS.

According to Argilés, Slof (2001), even in 2001 it was observed that there was a gap between the importance attached to the accounting and low level of accounting and bookkeeping practices in the agricultural sector. The reasons for this gap were poor adaptation of accounting rules to specific characteristics of agriculture and their difficult and expensive implementation. Despite the relative importance for the economy in many countries and growing links with other sectors, agriculture is traditionally not given much attention by researchers engaged in accounting (Argilés, Slof, 2001). On the other hand, it is generally believed that accounting can improve the management of agricultural enterprises and lead to achievement of better performances. Even Garcia, Sonka, Mazzacco (1983) in the research found that farmers drafting the financial statements could more easily make a projection of the cash flows than those who were not involved in financial accounting. Both the creditors', as well as the different needs of economic policy makers are also expressed through the needs for different information in the agricultural sector, in particular for accounting information. Thus, we can conclude that there are external requirements for accounting information in agriculture and that the information may also be useful to the farmers as well (Argilés, Slof, 2001). Besides that, Savić, Vasiljević, Đorđević (2014) discusses the challenges and specifics of cost management support for financial and managerial accounting in the agribusiness enterprises.

The Farm Accountancy Data Network (FADN) is a European system of testing the samples conducting every year the collection of accounting data from agricultural enterprises (farms), with the aim of monitoring the income and business activities of agricultural enterprises in the EU (European Commission, 2015). In addition, the FADN is an important source of information for understanding the impact of the measures taken under the Common Agricultural Policy (Vasile, Dorel, Mihai, 2015) in various types of agricultural enterprises (European Commission Directorate-general for agriculture and rural development, February 2014).

In EU Dairy farms report 2013 three different margin indicators are studied. The gross margin (over operating costs) is mostly applied in making comparisons with alternative types of production (labor, land and capital costs still have to be paid, regardless of the production type chosen). The net margin (prior to own factors) is calculated as the gross margin minus depreciation and external factors (wages, interest paid, rent). The net economic margin enables the assessment of the residual revenue (profit or loss) obtained from production, after remuneration of all production factors including imputed family factors (opportunity costs of family factors) (European Commission Directorate-general for agriculture and rural development, February 2014).

EU Dairy farms report 2013 in particular analyzes the structural information on milk specialized farms in the EU member states. The analyses source is EU FADN, Eurostat production statistics. Figure 1 and Figure 2 present the Milk production farms (tons) 
and Share of national milk production for 2011 of the EU countries, except Greece and Cyprus for which the data are not displayed due to fewer than 15 farms in the sample.

Figure 1. Milk farm production (tons) for 2011

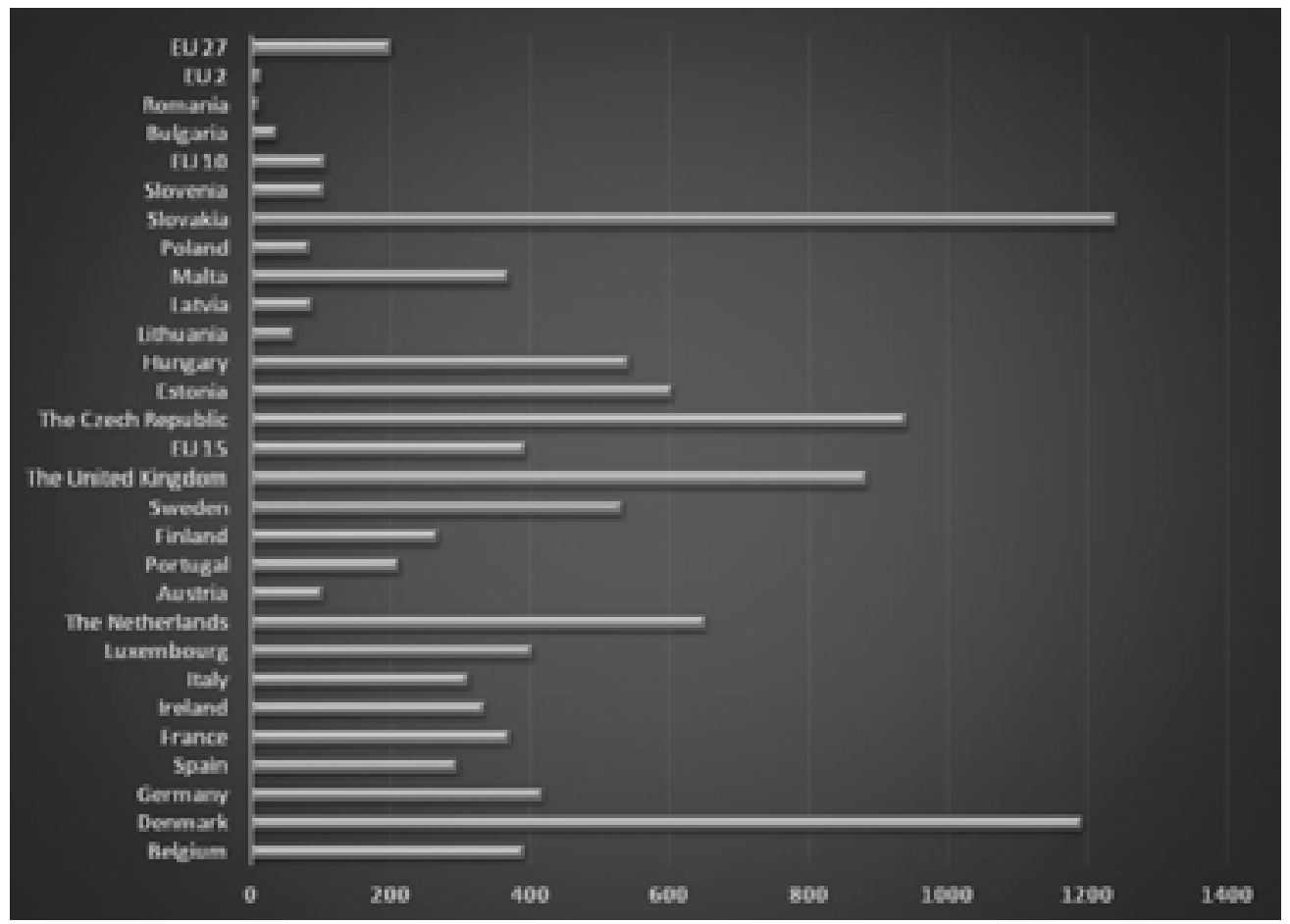

Source: European Commission Directorate-general for agriculture and rural development, (February 2014)

The maximum amount of milk production/farm-tons in 2011 from all the EU countries surveyed had Slovakia and Denmark and it being in 1242 and 1193 farms - tons, while Romania had the lowest amount of Milk production/farm-tons in the same year, 14 farms-tons. Romanian market is dominated by $80 \%$ of small farms that are not competitive and the level of production is low (Chelmu, 2012). 


\section{Figure 2. Share of national milk production for 2011}

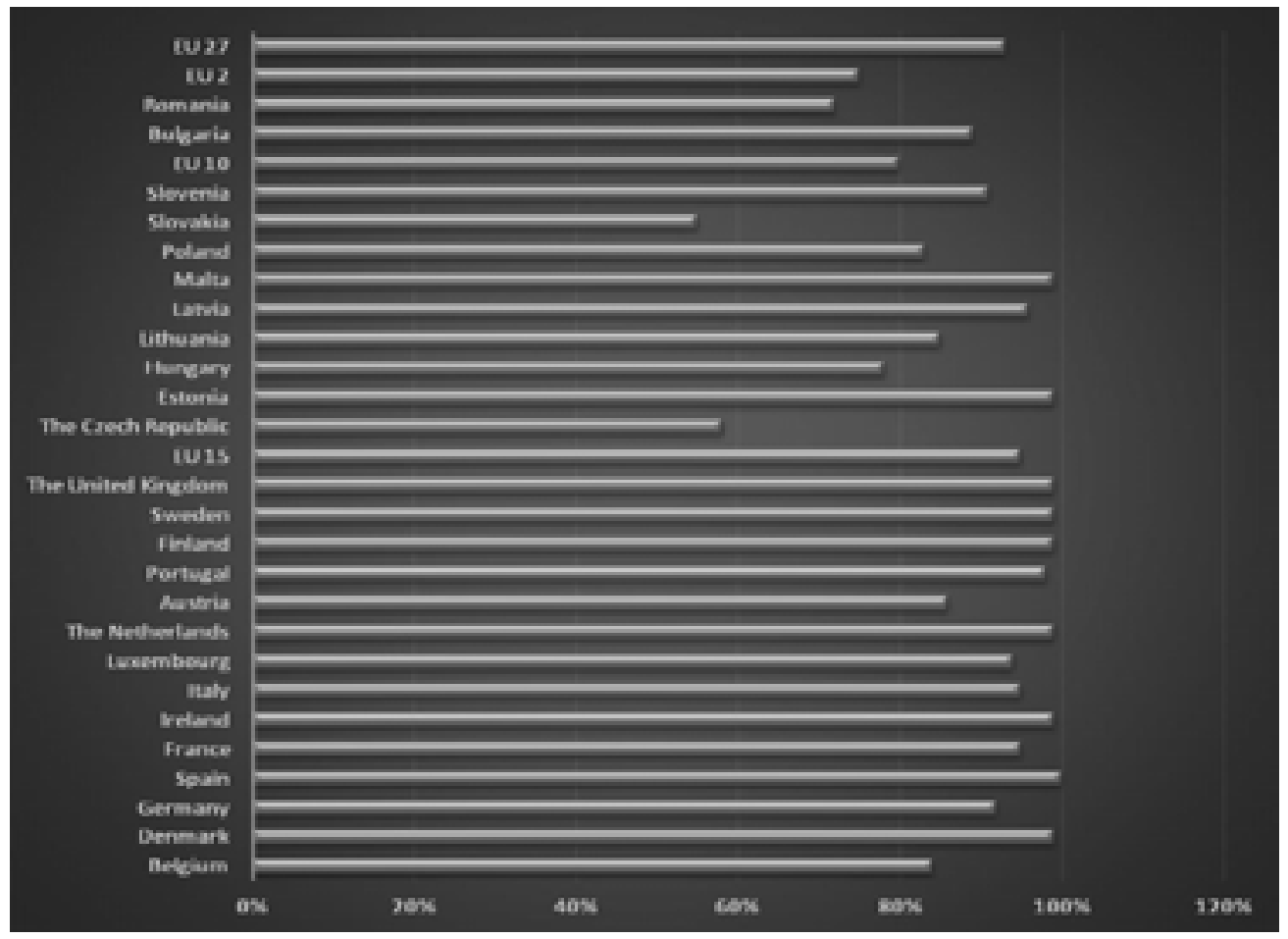

Source: European Commission Directorate-general for agriculture and rural development, (February 2014)

If we observe Share of national milk production - \% in 2011 in all EU countries surveyed (Figure 2), it is noted that 15 EU member states achieve far higher Share of national milk production -\% compared to the EU 10 and EU 2. The greatest share of national milk production -\% in 2011 achieved Spain (100\%), while Slovakia and the Czech Republic recorded the lowest participation in Share of national milk production $-\%, 55 \%$ and $58 \%$ respectively.

Considering the official statistics of the Republic of Serbia, concerning changes in the number of companies and agricultural cooperatives and agricultural holdings in the period from 2009 to 2013, we realize the following: during the period from 2009 to 2011 there was a decreasing trend in the number of companies and agricultural cooperatives, and in 2012 this number was increased by several times (from 712 to 3000), while in the case of family farms in 2012 the number was reduced from 778891 to 628552 (Statistical Office of the Republic of Serbia (2015). In study of Vehapi, Šabotić (2015) identify the most important problems of Serbian agriculture, among others unfavorable ownership structure and low productivity.

Observing the milk production in the Republic of Serbia, also from 2009 to 2013, there was a downward trend in milk production in million liters from year to year, except in 
2012, when the milk production compared to the year 2011 increased by 8 mill.litres (Table 1). The small farmers participate significantly in the total cow milk production in Serbia and their dominant position is a result of declining farms (Drašković, Rajković, Kostić, 2010).

Table 1. Milk production in million liters*

\begin{tabular}{|l|r|r|r|r|r|}
\hline & $\mathbf{2 0 0 9}$ & $\mathbf{2 0 1 0}$ & $\mathbf{2 0 1 1}$ & $\mathbf{2 0 1 2}$ & $\mathbf{2 0 1 3}$ \\
\hline Total & 1489 & 1462 & 1445 & 1453 & 1432 \\
\hline
\end{tabular}

Source: Statistical Office of the Republic of Serbia (2015)

*Cow and sheep milk for human consumption and processing

\section{Financial analysis techniques}

The analysis of financial data uses a variety of techniques to evaluate the financial position of an enterprise. Techniques applied are - ratio analysis, common-size analysis, review of descriptive material and comparisons of the results obtained with other types of data.

Understanding financial ratios, it is possible to gain insight into the financial status of the company. Information from three key financial statements - balance sheet, income statement and cash flow statement are the basis for the application of ratio analysis. These financial measurements should be carried out every year in order to determine the financial progress of a dairy company. The companies that survive and prosper must have managers who use the tools of financial analysis to check the vital financial functions (Barnard, Akridge, Dooley, Foltz, 2012).

The DuPont Analysis was created by the DuPont Corporation in the 1920s. This analysis is one of the most popular techniques of identifying the strengths and weaknesses of a dairy enterprise. Low value of Return on equity relative to the average of the branch or its decline may indicate the appropriate problems or weakness. As potential sources of weakness within the family dairies the following can be specified: management inefficiency, poor cost controls, inefficient production or inadequate marketing. By decomposition of synthesized indicators weaknesses can be more accurately assessed, and significant information signals van be obtained to initiate appropriate actions by management to retrieve financial performance, which is illustrated in the following table: 
Table 2. The DuPont Analysis - Family Dairy $\mathbf{X}$ and Family Dairy $\mathbf{Y}$

\begin{tabular}{|l|r|r|}
\hline Elements & Family Dairy $\mathbf{X}$ & Family Dairy $\mathbf{Y}$ \\
\hline 1. Operating profit margin ratio & 0,29 & 0,11 \\
\hline 2. Asset turnover ratio & 0,20689 & 0,3909 \\
\hline 3. Return on assets - ROA (1 x 2) & 0,060 & 0,043 \\
\hline 4. Interest expense to farm assets & 0,05091 & 0,03247 \\
\hline 5. Equity multiplier (EM shows financial leverage) & 2,2 & 1,90 \\
\hline 6. Return on equity - ROE (3 - 4) $\mathbf{5}$ & $0,02(2 \%)$ & $0,02(\mathbf{2} \%)$ \\
\hline
\end{tabular}

Source: Author's Analysis

Malinić, Milićević, Stevanović (2012) emphasize that asset turnover multiplies the effect of increasing the profitability of revenue to profitability of total investment in a company property. The attached table shows that both family dairies have $2 \%$ ROE. However, by applying leverage the DuPont system can be seen to have different sources of weakness. Family dairy $\mathbf{X}$ has a higher operating profit margin ratio while lower asset turnover in relation to family dairy $\mathbf{Y}$. In addition, the Family dairy $\mathbf{X}$ has a higher leverage ratio (equity multiplier) than the Family dairy $\mathbf{Y}(2,2: 1,90)$, and it is important to bear in mind the fact that corporate borrowing may lead to positive or negative effect on the profitability of equity capital.

To improve the assets turnover ratio, in the case of family dairy $\mathbf{X}$, it is essential that the management of the family dairy undertake activities that will lead to higher production efficiency or improve the price level in the sense that it reduces the cost, and can also reduce current or non-current assets. Observing the profit margin as a very important financial indicator, for the family dairy $\mathbf{Y}$, efforts are expected of management towards increasing production efficiency, improving the price level or reducing costs more than revenues.

It is not sufficient to say that one or the other dairy enterprise is more profitable than the other, but one must consider both the causes and factors that have likely opted for the decision. The objective of the analysis of financial statements is of great importance, because for example, one approach to comparing the two dairy enterprises will differ from the approach to the assessment of investments' profitability in the two enterprises. The management could use the financial reports to determine the enterprises' profitability.

In the financial analysis standards are used that were created on the basis of experience, respecting the particularity of certain industry and they were modified from time to time with changes in business conditions of dairy companies or companies that operate in another industry. The standards may be ideal or average, or normal achievements to be achieved under certain conditions. Due to the variable nature of the standards, constant learning about conditions under which they were established is essential, so that the causes of deviations from the standards must be respected. The standard relations provide a benchmark for comparison and significance of calculated ratio numbers can be understood only when compared with another ratio, and thus we can speak of four types of standards (Kumar, 1985): 
- Absolute standards: - These indicators represent certain rules, for example, in case of ratios of general liquidity where the orientation norm is ratio $2: 1$.

- Historical Standards: - These indicators represent the previous ratios of surveyed dairy companies. Comparison with historical standards is also known as the "trend analysis".

- Horizontal standards: - These are average indicators calculated for the entire dairy industry or for comparison between the two companies. Comparison within these standards is a complex issue because of the difference in size of the observed companies, the accounting policies that were applied and defined objectives, regardless of the companies operating in the same industry.

- Budget Standards: - These standards are based on the budget and are applied so that the actual ratio figures are compared with budgeted indicators, thus making them useful for internal management in the function of performance evaluation and control in dairy and other enterprises.

\section{A practical example: Ratio and SWOT analysis of the enterprise: "Family dairy Veličković"}

The family dairy Veličković has a long tradition in the production of milk and dairy products. The dairy now has 22 employees and processes about 5,500 liters of milk on a daily basis. From the purchase, processing and dairy production as core business, investing in modern technology, employees and cooperation with foreign experts their own line of products has been developed. Today in retail stores the company sells more types of products (yogurt, cream, cheese and sour cream). The structure of financing sources was as follows:

Table 3. Structure of financing sources for the years 2014 and 2013, Family Dairy Veličković, Surdulica

\begin{tabular}{|l|r|}
\hline Financing sources & 2014 year \\
\hline Equity & $55,83 \%$ \\
\hline Long-term liabilities & $14,99 \%$ \\
\hline Short-term liabilities & $29,17 \%$ \\
\hline & $\mathbf{1 0 0 \%}$ \\
\hline
\end{tabular}

Source: Author's Analysis (Balance sheet, 2014)

Net sales revenue, gross profit and net profit grow in the current compared to the previous year, indicating a positive trend. However, for a more accurate evaluation, it is necessary to determine the quality of revenue and profits by comparing them with cash flow. Dairy additionally indebted in 2014 by taking a long-term loan at the bank to invest in a cooling chamber which affected the investing activities in the cash flow statement, as well as the financing activities; and a short-term loan to provide liquidity, which had been impaired due to problems in the inability to collect large amounts of receivables.

EP 2015 (62) 4 (1061-1078) 
Table 4. Components of profitability for the years 2014 and 2013, Family Dairy Veličković, Surdulica in RSD

\begin{tabular}{|l|r|r|}
\hline Components of profitability & 2014 year & 2013 year \\
\hline Net sales & 57.737 .000 & 36.821 .000 \\
\hline Operating income & 1.336 .000 & 1.165 .000 \\
\hline Net income & 537.000 & 414.000 \\
\hline
\end{tabular}

Source: Author's Analysis (Income statement, 2013, 2014)

The increase was influenced by the growth of profit in current profit compared to the previous year and most of the paid off credit obligations.

The dairy generally applies strategy of low profit margins and high ratio of current assets. The reason for choosing this strategy is that the dairy primarily produces inferior products, while luxury products have a low share in the total range. The strategy is to produce dairy products that will be cheaper than the competing ones. This is relatively possible to realize, because as the comparative advantage can be taken - cheap labor, low transportation costs, cheap raw materials and more. In order to achieve as high profit as possible, it is necessary that the diary realizes economy of scale.

When it comes to luxury dairy products, which have less than $10 \%$ share in total production, a high profit margin and lower turnover ratio of these stocks is applied.

The structure of assets and their sources is presented below:

Figure 3. The structure of assets

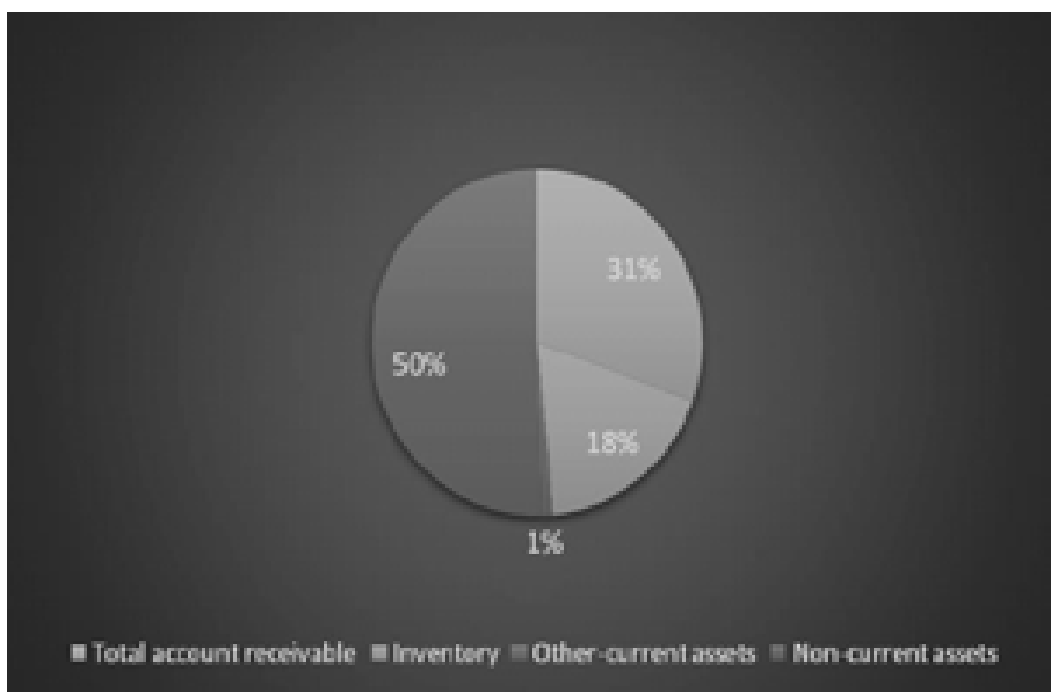

Source: Author's Analysis (Balance sheet for 2014) 
Figure 4. The structure of sources of assets, Family Dairy Veličković, Surdulica in RSD

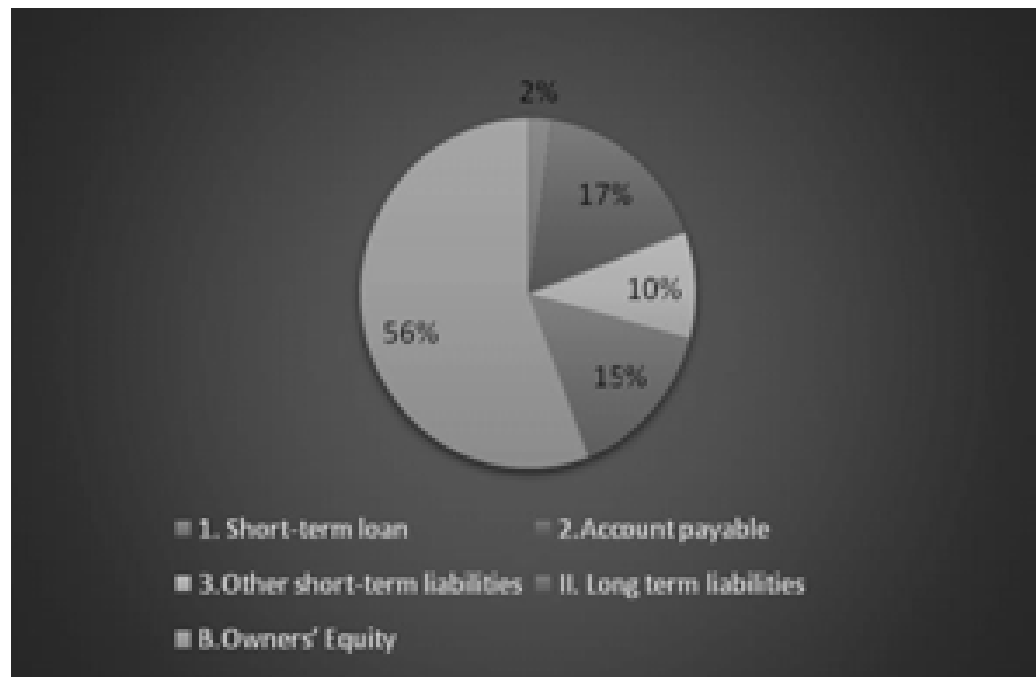

Source: Author's Analysis (Balance sheet for 2014)

In 2014 predominant in the structure of total revenues are operating revenues (almost $99 \%$, Income statement).

Below is the structure of operating expenses showing that the material costs were the largest share in both years, and that in 2014 there was a growth of all types of operating costs compared to the previous year, which resulted in the largest extent due to the increased volume of business (Figure 5).

Figure 5. The structure of operating expenses in RSD

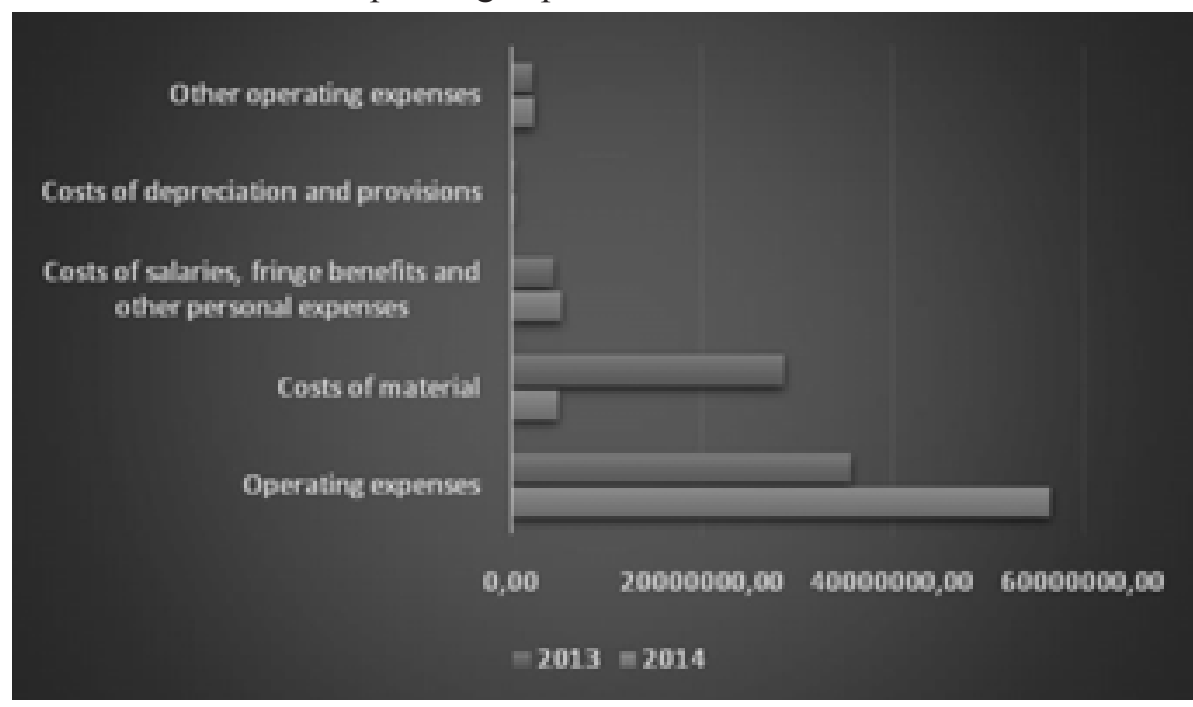

Source: Author's Analysis (Income statement, 2013, 2014)

EP 2015 (62) 4 (1061-1078) 
Tables 5 and 6 show the loss of funding in both years, which in 2014 decreased due to lower burden of the dairy by interest obligations, and the difference between other revenues and other expenses, which is also negative in both years with an increase tendency of $12.74 \%$.

Table 5. The difference between financial revenues and financial expenses in RSD

\begin{tabular}{|l|r|r|}
\hline \multicolumn{1}{|c|}{ ITEMS } & 2014 & 2013 \\
\hline $\begin{array}{l}\text { The difference between financial revenues and financial } \\
\text { expenses }\end{array}$ & $(100.000)$ & $(131.000)$ \\
\hline $\begin{array}{l}\text { \% of change in difference between financial revenues and } \\
\text { financial expenses }\end{array}$ & $23,66 \%-$ & \\
\hline Financial items & & 16.000 \\
\hline in which: Financial revenues & 2.000 & 147.000 \\
\hline Financial expenses & 102.000 & $-87,5 \%$ \\
\hline$\%$ change in Financial revenues & & $-30,61 \%$ \\
\hline$\%$ change in Financial expenses & & \\
\hline
\end{tabular}

Source: Author's Analysis (Income statement, 2013, 2014)

Table 6. Profit/(loss) from other activities in RSD and \% change

\begin{tabular}{|l|c|c|}
\hline \multicolumn{1}{|c|}{ ITEMS } & 2014 & 2013 \\
\hline Profit/(loss) from other activities & $\mathbf{( 6 9 9 . 0 0 0 )}$ & $\mathbf{( 6 2 0 . 0 0 0 )}$ \\
\hline$\%$ change in Profit/(loss) from other activities & $+12,74 \%$ & \\
\hline
\end{tabular}

Source: Author's Analysis (Income statement, 2013, 2014)

The most commonly used statistic liquidity ratios include the current ratio, quick ratio and net working capital to total assets ratio (Table 7). The following are the calculated values of ratios on the basis of which it is stated that the current ratio is below the reference norm of 2, and quick ratio as a more stringent test of liquidity is slightly above the reference norm of 1 . Net working capital to total asset ratio represents the ratio providing information on the liquidity by showing the percentage of total assets the dairy carries as net working capital, which in the observed dairy is $20,45 \%$ and the sole value of net working capital is positive and amounts to 2,957,000 RSD in 2014. The liquidity situation is generally satisfactory.

Table 7. Liquidity ratios

\begin{tabular}{|l|r|}
\hline LIQUIDITY RATIO & \multicolumn{1}{|c|}{2014} \\
\hline Current ratio & 1,70 \\
\hline Quick ratio & 1,09 \\
\hline Net working capital to total asset & $20,45 \%$ \\
\hline
\end{tabular}

Source: Author's Analysis (Balance sheet, 2014) 
After the analysis of liquidity, the logical sequence is the analysis of long-term financial security (Table 8). Long-term creditors generally start from the point that their claims are safe to the extent in which a firm owns its own capital. In the observed case, only $44.16 \%$ of dairy assets are financed by debt. Conversely, the dairy finances 55,83\% of its assets. Thus, the interest earned ratio serves as a measurement of available area between interest expense and earnings of the enterprise, a larger area indicates a greater degree of certainty in terms of collateral for long-term creditors, which for the observed dairy is 7 times.

Table 8. Long-term solvency ratio

\begin{tabular}{|l|r|}
\hline LEVERAGE RATIO & \multicolumn{1}{|c|}{2014} \\
\hline Liabilities / Total assets & $44,16 \%(0,4416)$ \\
\hline Liabilities / Equity & $79,09 \%(0,7909)$ \\
\hline Equity multiplier (Total assets/ total equity) & 1,791 \\
\hline Time interest earned ratio & 7 times \\
\hline
\end{tabular}

Source: Author's Analysis (Balance sheet and Income statement, 2014)

Further analyzed, is the efficiency of asset management and capital management called in the relevant academic literature turnover analysis (Table 9). More efficient management, primarily over current assets with a focus on inventory and accounts receivable, leads to faster release of cash that is necessary to pay short-term obligations to creditors, which significantly affects the liquidity. Kneževic, Fabris (2010) emphasize that unlike receivables where the collection for the most part depends on the buyer, the decision on the moment of paying to their suppliers is made by the management. It is important to bear in mind that the decision in addition to the agreed currency will depend on the current liquidity and naturally on the general strength and market position of the enterprise. It happens in practice that small and medium enterprises are endangered by delayed payments from large, powerful companies that settle their liabilities with a considerable delay and thus they are financed by free "overdraft". For a more precise interpretation of turnover ratios it is necessary to have information on reference norm for the industry in which the observed enterprise operates for comparison with its competitors. From the aspect of performance and safety, it is always better that the turnover ratio is as great figure as possible and the binding time of certain parts of the property as short as possible. Duration of inventory turnover was 16 days. The average collection period of trade receivables was 28 days and the dairy had liquidity problems due to the inability to collect the greater part of trade receivables, so the strategy was changed in the field of credit policy. Sales were diverted into new solvent customers and cooperation with insolvent customers was interrupted. In addition, the payment period is shortened, and to customers who did not respect the agreed deadlines, the delivery of goods was terminated till the payment. 
Total asset turnover shows assets utilization efficiency. Every dinar invested in assets generated net sales of 3.99 dinars.

Table 9. Asset management ratio

\begin{tabular}{|l|r|}
\hline ASSET MANAGEMENT RATIO & 2014 \\
\hline Inventory turnover & 22 times \\
\hline Duration of inventory turnover & 16 days \\
\hline Receivable turnover & 13 times \\
\hline Duration of collection of receivables & 28 days \\
\hline \multicolumn{2}{r|}{ Total asset turnover } \\
\hline
\end{tabular}

Source: Author's Analysis (Balance sheet and Income statement, 2013, 2014)

In the context of the profitability indicators following, considered are - an indicator of profit margin, the profitability of total assets and profitability of its own capital (Table $10)$. The rate of return on equity (ROE) was higher than the rate of return on assets (ROA), which means it pays off to use someone else's capital (positive impact of financial leverage).

Table 10. Profitability ratios

\begin{tabular}{|l|r|}
\hline PROFITABILITY RATIOS & \multicolumn{1}{c|}{2014} \\
\hline Profit margin & $\mathbf{9 3 , 0 0 7 9 4}$ \\
\hline Return on assets(ROA) & $\mathbf{2 , 3 7 3 2 4 \%}$ \\
\hline Return on equity(ROE) & $\mathbf{6 , 6 5 0 9 8 \%}$ \\
\hline Financial leverage & 1,790934 \\
\hline
\end{tabular}

Source: Author's Analysis (Balance sheet and Income statement, 2013, 2014)

The logic of DuPont system of profitability analysis was applied as follows:

Table 11. DuPont analysis

\begin{tabular}{|l|r|}
\hline COMPONENTS & \multicolumn{1}{|c|}{2014} \\
\hline Profit margin & $\mathbf{9 3 , 0 0 7 9 4} \%$ \\
\hline X Total asset turnover & $\mathbf{3 , 9 9}$ \\
\hline X Financial leverage & $\mathbf{1 , 7 9 0 9 3 4}$ \\
\hline ROE & $\mathbf{6 , 6 5 \%}$ \\
\hline
\end{tabular}

Source: Author's Analysis (Balance sheet and Income statement, 2014) 
Given that dairy observed continuously examines the potential for new products, the paper also presents a SWOT analysis that can determine the likely risks and rewards, and find the most promising new market:

Figure 6. SWOT Analysis

\begin{tabular}{|c|c|}
\hline $\begin{array}{l}\text { Strengths } \\
\text { 1. Currently available sufficient } \\
\text { quantities of milk to purchase } \\
\text { 2. Existing capacities } \\
\text { 3. Partially conquered market } \\
\text { 4. Investigated needs of the local } \\
\text { market and the possibility of selling } \\
\text { in markets outside Pcinja District } \\
\text { 5. Professional and experienced staff } \\
\text { 6. Professional and experienced staff } \\
\text { 7. Exports to Macedonia (CEFTA) }\end{array}$ & $\begin{array}{l}\text { Weaknesses } \\
\text { 1. Lack of large farms } \\
\text { 2. Distance from the major centers } \\
\text { 3. Low level of net working capital } \\
\text { 4. Lack of economies of seale } \\
\text { 5. Technologically outdated } \\
\text { equapment }\end{array}$ \\
\hline $\begin{array}{l}\text { Opportunities } \\
\text { 1. Organization of purchase on the } \\
\text { uncovered areas } \\
2 \text { High quality of existing products } \\
\text { 3.Manufacturing products with long } \\
\text { shelf life } \\
\text { 4. Expansion of exports to other } \\
\text { countries - CEFTA, Russia and the EU } \\
5 \text { Better relationships with } \\
\text { subcontractors }\end{array}$ & $\begin{array}{l}\text { Threats } \\
\text { 1.The presence of large dairies on the } \\
\text { market and lower product prices, } \\
\text { which is unfavorable to competition } \\
\text { 2.The demographic problem } \\
\text { 3. Insufficient incentives } \\
\text { 4.The exastence of irregular market } \\
\text { 5. Imports of raw milk and products } \\
\text { from the EU under the inadequate } \\
\text { control }\end{array}$ \\
\hline
\end{tabular}

Source: Author's Analysis

Based on the presented SWOT analysis it can be seen that there is a possibility of expanding the market beyond the local on which the observed family dairy operates and that is one of the key preconditions of acquisition of newer technological equipment. 


\section{Conclusion}

Financial information is used to meet the following needs of agricultural enterprises for decision-making, as well as for financial reporting purposes. The financial statements of any agricultural enterprise provide a wealth of information for managers. In the financial statements useful information can be found, which are not obvious so that agricultural enterprises should have managers using the tools of financial analysis. Speaking about the reporting of financial performance in family dairies, the basis is created for displaying techniques of financial analysis.

External analysts usually use historical and/or horizontal standards. Accounting information is not focused only on financial performance, but also on the use of financial indicators which can be managed. In family dairies of any size and organizational structure, there is a need to monitor and present variety of different activities aimed at a common unit or measure. The effect of different activities can be aggregated into financial metrics such as revenue from sales, profits and costs that are used to compare the actual performance and evaluation of the financial status of the agricultural enterprises focusing on companies engaged in dairying. The DuPont analysis can be successfully used to identify the strengths and weaknesses of a dairy.

It is not sufficient to say that one or the other dairy enterprise is more profitable than the other, but one must consider both the causes and factors that have likely opted for the decision. Financial ratios cannot directly provide answers to important questions about the company, so this paper represent the basis for identifying relationships based on which, by comparing the achieved performances and certain business standards, the differences or variations are identified. After that, the management of the dairy is the one that should initiate appropriate actions that may lead to the correction of financial performance of dairy.

\section{References}

1. Alsos, G. A., Ljunggren, E., Pettersen, L.T. (2003): Farm-based entrepreneurs: what triggers the start-up of new business activities?, Journal of Small Business and Enterprise Development, Vol. 10, No. 4, pp. 435-443.

2. Argilés J. M., Slof E. J. (2001): New opportunities for farm accounting, European Accounting Review, Vol. 10, No. 2, pp. 361-383.

3. Barnard, F., Akridge,J., Dooley, F., Foltz, J. (2012): Agribusiness Management, Routledge, Taylor \& Francis Group, London and New York. (ISBN 978-0-41559695-4).

4. Chelmu, S. S. (2012): Competitiveness of agricultural products on the meat-dairy chain. Economics of Agriculture, Vol. 59, No. SI-1, pp. 29-37.

5. Drašković, B., Rajković, Z., Kostić, D. (2010): Milk production in Serbia and position small farmers. Economics of Agriculture, Vol. 57, No. 4, pp. 529-541.

6. European Commission. Agriculture and Rural Development. Farm Accountancy 
Data Network $(F A D N)$. (available at: http://ec.europa.eu/agriculture/fadn/index en.htm)

7. European Commission Directorate-general for agriculture and rural development. (February 2014): EU Dairy farms report 2013. European Union, Brussels. (available at: http://ec.europa.eu/agriculture/ricaprod/pdf/Dairy_Farms report 2013 WEB. pdf)

8. Family dairy Veličković. (available at: http://www.mlekaravelickovic.rs/general. php?id=2)

9. Garcia, P., Sonka, S. T., Mazzacco, M. A. (1983): A Multivariate Logit Analysis of Farmers' Use of Financial Information, American Journal of Agricultural Economics, Vol. 65, No. 1, pp.136-141.

10. Geman, H. (2015): Agricultural finance : from crops to land, water and infrastructure. John Wiley \& Sons Ltd, The Atrium, Southern Gate, Chichester, West Sussex, PO19 8SQ, United Kingdom. (ISBN 978-1-118-82738-3).

11. Knežević S., Fabris M. (2010): Upravljanje obrtnim sredstvima i kratkoročnim obavezama, Računovodstvo, Savez računovođa i revizora Srbije, Beograd, No. 1112, pp. 61-73.

12. Kumar,A.(1985): Standards for comparison under Ratio Analysis, The Management Reporter, Tribhuvan University, Nepal. Vol. 2, No. 2.

13. Malinić D., Milićević V., Stevanović N. (2012): Upravljačko računovodstvo, Ekonomski fakultet, Beograd. (ISBN 978-86-403-1203-5).

14. McElwee, G. (2005): Developing entrepreneurial skills of farmers, SSPECT-2005-006500, D2: A Literature review of entrepreneurship in agriculture. (available at: http://www.esofarmers.org/fileadmin/esofarmers/documents/ ESoFliteraturereview_000.pdf)

15. Milošević, V. (1997): Teorija troškova: troškovi preduzeća, Prosveta, Niš. (ISBN 86-7455-302-8).

16. Pyysiäinen, J., Anderson, A., McElwee, G., Vesala, K. (2006): Developing the entrepreneurial skills of farmers: some myths explored, International Journal of Entrepreneurial Behavior \& Research, Vol. 12, No. 1, pp. 21-39.

17. Savić, B., Vasiljević, Z., Đorđević, D. (2014): Strategic cost management as instrument for improving competitiveness of agribusiness complex, Economics of Agriculture, Vol. 61, No. 4, pp. 1005-1020.

18. Statistical Office of the Republic of Serbia. (2015): The Statistical Pocketbook of the Republic of Serbia 2015, Belgrade. (available at: http://webrzs.stat.gov.rs/WebSite/ repository/documents/00/01/71/83/Statisticki_kalendar_Republike_Srbije_2015. pdf)

19. Vasile, A. J., Dorel, D., Mihai, M. (2015): The influences of the cultural models on agricultural production structures in Romania and some EU-28 countries - a perspective. Economics of Agriculture, Vol. 62, No. 2, pp. 293-307. 
20. Vehapi, S., Šabotić, Z. (2015): The state and problems of Serbian agriculture. Economics of Agriculture, Vol. 62, No. 1, pp. 245-257.

\title{
SPECIFIČNOSTI RACIO ANALIZE FINANSIJSKIH IZVEŠTAJA PORODIČNIH MLEKARA
}

\author{
Aleksandra Mitrovič́, Snežana Kneževič ${ }^{5}$, Milica Veličkovićc ${ }^{6}$
}

\begin{abstract}
Rezime
Predmet istraživanja ovog rada predstavlja evaluiranje specifičnosti finansijske analize mlekarskih preduzeća sa fokusom na primenu racio analize finansijskih izveštaja. Racio analiza predstavlja središnji deo finansijske analize, jer je zasnovana na ispitivanju odnosa između logički povezanih stavki u finansijskim izveštajima radi ocene finansijskog položaja posmatranog preduzeća i njegove zarađivačke sposobnosti. Govoreći o izveštavanju o finansijskim performansama u porodičnim mlekarama, stvorena je osnova prikaza tehnika finansijske analize, sa posebnim ukazom na specifičnosti njihove primene kod poljoprivrednih preduzeća sa fokusom na preduzeća koja se bave mlekarstvom. U radu je primenjena racio analiza na primeru mlekarskog preduzeća, odnosno porodične mlekare koja posluje u Srbiji. Racio pokazatelji predstavljaju osnovu za identifikovanje odnosa na osnovu koga se poređenjem ostvarenih performansi i određenih standarda poslovanja, identifikuju razlike ili varijacije.
\end{abstract}

Ključne reči: finansijska analiza, finansijska racija, porodična mlekara, upravljanje, finansijske performanse.

4 Asistent, mr Aleksandra Mitrović, Univerzitet u Kragujevcu, Fakultet za hotelijerstvo i turizam, Vojvođanska 5a, Vrnjačka Banja, Srbija, Telefon: +381 36515 0024; E-mail: aleksandra.stankovic@kg.ac.rs

5 Vanredni profesor, dr Snežana Knežević, Univerzitet u Beogradu, Fakultet organizacionih nauka, Jove Ilića 154, 11000 Beograd, Srbija, Telefon: +381 1139508 75; E-mail: snezana.knezevic@,fon.bg.ac.rs

6 Milica Veličković, menadžer izvoza, Porodična mlekara Veličković, Alakince, 17530 Surdulica, Srbija, Telefon: +381 178120 99; E-mail: velimilk@hotmail.com 